\title{
EFFECT OF LACTATION LENGTH AND LITTER SIZE ON MILK COMPOSITION OF BOER GOAT WITHIN ONE MONTH OF PARTURITION
}

\author{
Sagar REGMI ${ }^{\circledR 凶}$, Premlal MAHATO ${ }^{1}$ and Khagendra Raj SAPKOTA ${ }^{2}$ \\ ${ }^{1}$ Agriculture and Forestry University, Rampur, Chitwan, Nepal \\ ${ }^{2}$ National Livestock Breeding Office, Pokhara, Nepal \\ Email: saregme@gmail.com; (D) ORCID: 0000-0003-1856-8780 \\ Supporting Information
}

\begin{abstract}
The aim of this study was to determine the effect of lactation length and litter size on the milk composition of Boer goats. Milk samples from 23 lactating Boer goats reared in NLBO (National Livestock Breeding Office), Pokhara, Nepal, were collected and analyzed in a laboratory present within a farm. Goats were reared under the same environment and provided with similar care and management. Lactation length showed a non-significant effect on fat content in the milk whereas all other constituents were influenced significantly. Similarly, litter size showed a significant effect on the freezing point of milk only. Litter size and all milk constituents were negatively correlated. However, Litter size and freezing point showed moderately strong correlation. Twinning did not significant influence fat, protein, lactose and solids nonfat content of goat milk. All constituents were weakly correlated to litter size however freezing point showed moderately strong correlation. Thus, more focus must be given to the nutritional management of triplets and twins to improve their growth rate compared to a single kid.
\end{abstract}

Keywords: Boer goat, Lactation length, Milk composition, Litter size, Twinning.

\section{INTRODUCTION}

Boer goats (Capra aegagrus hircus) are one of the most desirable goat breeds with good meat conformation, short hair and a variety of color patterns and are believed to be the result of a genetic pooling of African indigenous goats, Indians goats, Angora goats, and European dairy goats (Lu, 2001). Boer goats were believed to be brought in Nepal around 1999 A.D. Boer goats started being reared for detailed research in Goat Research Center, Bandipur in 2008 A.D (Nepali, 2016). Its demand has been increasing worldwide for its excellent body conformation, fast-growing rate, and good carcass quality (Lu, 2001). Boer breed has higher immunity to diseases and quicker maturity than our local breeds. The growth rate of Boer kids was found to be 150- 300 grams per day (Nepali, 2016). The average growth rates were also recorded as 291, 272,245 , and $250 \mathrm{~g} /$ day in male goats and 272, 240, 204, and $186 \mathrm{~g} /$ day in female goats from birth to 100, 150, 210, and 270 days of age respectively (Lu, 2001). Multiple kids can easily be reared as it produces an adequate amount of milk during lactation.

Two percent of the world's total annual milk supply is maintained by goats. Goat milk possesses higher digestibility of protein and fat, alkalinity, buffering capacity, and certain therapeutic values over a cow or human milk (Park, 2009). Goat milk has significantly higher protein and ash, but lower lactose, than human milk (Park, 2009). It can therefore be considered as the main replacement of cow's milk for lactose intolerant individual (Kalyankar et. al., 2016). Goat milk is richer in caproic, caprylic, and capric acids than cow milk with 6, 8, and 10 carbon atoms, respectively (Chilliard, 1997). It is composed of medium-chain fatty acids (8-12 carbon atoms) that are efficient antimicrobials (Desbois and Smith, 2010). Goat milk is rich in calcium and phosphorus and is consumed in many regions, such as the Middle East, southern Asia, and some tropical countries.

Milk composition is affected by multiple factors like age, breed (Sung et al., 1999), nutrition, parity, stage of lactation (Ciappesoni et. al., 2004), environment, fodder, the season of kidding (Crepaldi et. al., 1999), etc. The main aim of this paper was to determine the effect of lactation length and litter size on milk constituent's i.e. fat, lactose, Solids Non Fat (S.NF), protein, and freezing point. Various researches have been carried out to determine the composition and factors affecting the composition of goat milk. However, there is limited information specific to Boer goats in the Nepalese environment during the early stage of lactation. 


\section{Study area}

Milk samples were collected from Boer goats reared under the intensive system in NLBO, Pokhara primarily for research purpose and up-grading of local breed. The research site is located within longitude $83^{\circ} 58^{\prime} 20.604^{\prime \prime} E$ and latitude $28^{\circ} 15^{\prime} 48.996^{\prime \prime} \mathrm{N}$ at an altitude of about $793 \mathrm{~m}$ above sea level (Figure 1). Twenty three Boer goats were lactating at the time of data collection. These therefore constituted the sample population. All goats were kept under the same environmental conditions and were provided with similar care and nutrition. Goats were fed with $600 \mathrm{gm}$ of concentrate per day. Ipil-Ipil (Leucaena leucocephala), Melia azadirachta, Ficus semicordata, etc. and Oat (Avena sativa), Sudan, Berseem, etc. were the major sources of fodder and forage respectively provided to the goats.

\section{Sample collection procedure}

- Goats were handled by two individuals in which one restrains the goat while the other one performs milking operation by hand.

- The teats were washed with clean water and rubbed with a clean towel to remove excess water.

- A total of $10 \mathrm{ml}$ of milk sample was collected from both teats in a sterile container to analyze the milk composition.

- The teats were cleaned again after milking was completed.

The collected milk sample was then taken to the laboratory located within the farm. The samples were homogenized before analysis using Akashganga Milk Analyzer, AMA-Mini-40. The data obtained were recorded and analyzed to determine the effect of lactation length on milk constituents.

\section{Data analysis}

Data regarding the age and lactation length was obtained from the recoding system present within the farm. The obtained data were recorded in an Excel sheet and were analyzed using IBM SPSS version 20 (Amos, 2011). The lactation length was divided into three categories as $2^{\text {nd }}, 3^{\text {rd }}$, and $4^{\text {th }}$ week of lactation. The relation between lactation length and milk constituents was analyzed using ANOVA test whereas an Independent sample T-test was used to determine the relationship between litter size and milk composition.

\section{RESULTS}

\section{Effect of lactation length on milk composition}

The effects of lactation length on milk composition are shown in Table 1. The study revealed that there was no significant effect $(p=0.232)$ of lactation length on the fat content of milk during the first month of lactation. The lowest fat percent was recorded on the $4^{\text {th }}$ week of lactation. Lactation length showed a significant effect $(p=0.041)$ on the Solids nonfat (S.N.F) content. Solids nonfat slightly decrease in $3^{\text {rd }}$ week but was elevated again on $4^{\text {th }}$ week. The freezing point showed a significant difference $(p=0.041)$ due to variation in lactation length. The trend in freezing point indicates a constant decrease with increase in lactation length. A significant effect $(p=0.042)$ of lactation length on the protein content of milk was also recorded during our study. Protein content was reduced during the $2^{\text {nd }}, 3^{\text {rd }}$, and $4^{\text {th }}$ week of lactation respectively. The lactose content of the milk was significantly affected $(p=0.049)$ by lactation length. Lowest lactose content was recorded at $3^{\text {rd }}$ week of lactation based on our study

\section{Effect of litter size on milk composition}

Results of our study revealed that fat, S.N.F, protein, and lactose content of milk showed no significant difference within 1 month of parturition due to variation in litter size (Table 2). All components are weakly correlated (negatively) to litter size except freezing point. Goat milk from does with two kids showed slightly lower fat, protein, lactose, and S.N.F content but insignificant compared to a goat with single kids (Table 2). The freezing point of milk showed significant variation $(p=0.043)$ with the number of kids. The freezing point was negatively correlated $(r=-0.424)$ to litter size similar to other milk constituents. 
Table 1 - Table showing the effect of lactation length on milk composition of Boer goats

\begin{tabular}{|c|c|c|c|c|}
\hline Lactation period (in days) & 7-14 & $15-21$ & $22-30$ & p-value \\
\hline Fat (\%) & $5.963 \pm 1.983$ & $6.150 \pm 1.801$ & $4.440 \pm 1.582$ & 0.232 \\
\hline S.N.F (\%) & $10.438 \pm 0.466$ & $9.930 \pm 0.414$ & $10.040 \pm 0.182$ & 0.041 \\
\hline Freezing point $(\mathrm{Fp})\left({ }^{\circ} \mathrm{C}\right)$ & $0.692 \pm 0.048$ & $0.654 \pm 0.024$ & $0.648 \pm 0.014$ & 0.041 \\
\hline Protein (\%) & $3.788 \pm 0.181$ & $3.610 \pm 0.152$ & $3.600 \pm 0.071$ & 0.042 \\
\hline Lactose (\%) & $5.700 \pm 0.278$ & $5.420 \pm 0.229$ & $5.460 \pm 0.114$ & 0.049 \\
\hline
\end{tabular}

Table 2 - Table showing the effect of litter size on milk composition of Boer goats

\begin{tabular}{|c|c|c|c|c|}
\hline No of kids & Single & Twins & $\begin{array}{l}\text { Correlation } \\
\text { coefficient (r) }\end{array}$ & p-value \\
\hline Fat (\%) & $6.44 \pm 2.357$ & $5.39 \pm 1.587$ & -0.263 & 0.225 \\
\hline S.N.F (\%) & $10.357 \pm 0.556$ & $10.031 \pm 0.366$ & -0.343 & 0.109 \\
\hline Freezing point $(\mathrm{Fp})\left({ }^{\circ} \mathrm{C}\right)$ & $0.689 \pm 0.056$ & $0.656 \pm 0.020$ & $-0.424^{*}$ & 0.043 \\
\hline Protein (\%) & $3.757 \pm 0.336$ & $3.631 \pm 0.130$ & -0.350 & 0.101 \\
\hline Lactose (\%) & $5.657 \pm 0.336$ & $5.469 \pm 0.199$ & -0.346 & 0.106 \\
\hline
\end{tabular}

\section{DISCUSSION}

The study performed by Idamokoro et al. (2017) was in line with our findings showing that the milk composition including fat showed no significant difference $(p>0.05)$ during the early, mid, and late stages of lactation. The mean fat percent of Boer milk was calculated to be $4.7 \%$ (Mestawet et al., 2012) which was lower than the result obtained within our study. The lower level of fat in goat milk is due to an increase in the molar percentage of propionic acid and the decline in the molar percentage of acetic acids found in the rumen (Morand-Fehr and Sauvant, 1980). But some researches in goats showed that the fat content in the milk gets slowly decreased in $\mathbf{3 0}$ days experimental period. The reason behind the decrease of milk fat can be explained by the increase in the percentage of monounsaturated fatty acids with the progress of lactation from $\mathbf{2 8 . 2} \%$ in colostrum to $\mathbf{3 3 . 0 \%}$ at $\mathbf{3 0}$ days post-partum at the expense of polyunsaturated fatty acid which is the main component of milk fat (Marounek et al., 2012). The average fat globule size of goat milk (3.5 $\mu \mathrm{m})$ is significantly smaller than that of cow milk $(4.5 \mu \mathrm{m})$ and goat milk possesses a higher percentage of small fat globules than that of cow milk (Knights and Garcia, 1997).

The average SNF content in the milk of Boer goats was observed to be $9.20 \pm 0.40 \%$ which is lower compared to our findings (Idamokoro et al., 2017). Mean S.N.F content of Boer goat's milk raised under the intensive and extensive system was obtained to be $10.4 \pm 6.5 \%$ and $10.7 \pm 5.1 \%$ respectively (Greyling et al., 2004). The research performed by Simos et al. (1996) explained that S.N.F content in the milk was determined by genetic factors rather than the energy intake of an animal.

The correlation coefficient between the freezing point and lactose content in the Boer milk was obtained to be 0.930 (strongly correlated) which is in line with the finding of Janštová et al. (2019) stating that freezing point of goat milk is influenced mainly by lactose and chlorides content in the milk. The proportion of milk constituents in a true solution determines the freezing point of milk and whose proportion of those constituents are affected by multiple factors like breed, the occurrence of subclinical mastitis, nutritional deficiencies, stage of lactation, water intake, thermal stress, and seasonal variation, presence of $\mathrm{CO} 2$ in milk, etc. (Slaghuis, 2001). The freezing point of the milk helps to determine the adulteration of water in the milk as it is the least variable component of milk in normal conditions (Zee, 1982).

Milk protein content tends to increase along with the advancement of the lactation period but this outcome didn't hold the truth in case of milk within a month after parturition based on the result obtained during our study (Singh, 1990). Proteins are composed of different amino-acids with $0.7-1.0 \% \mathrm{~N}$ and are influenced by breed, stage of lactation, feeding, climate, parity, season, and udder health status. Milk fat and protein content were determined mainly by the dietary energy balance (Sauvant et al., 1987).

A maximum of $5.27 \pm 1.05 \%$ lactose was recorded in the intensive feeding of Boer goats in week 5 which is in line with our results (Banda et al., 1992). The highest mean daily milk lactose content $(5.0 \pm 0.7 \%)$ was recorded by Boer does managed intensively (Greyling et al., 2004). Goat milk is often considered as a viable dairy option to those infants showing allergic reactions to both cow milk and soya-based formula because of its lower lactose content for lactose intolerant individuals. Our result was in agreement with Singh and Sengar (1979), who observed that lactose content showed a tendency to decline as the lactation period progresses.

The study of Zamuner et al. (2020) explained that the goats with single kids produce milk with higher fat\% and protein\% than goats delivering multiple kids. The subsequent decrease in milk fat, protein, lactose, and S.N.F content of Boer goat with single, twins, and triplets was recorded respectively (Lacasse et al., 2014). Goats nursing two kids produce 
more milk (Non-significant) than a single kid (Alkass and Merkhan, 2011). Milk yield and milk composition are negatively correlated (Simos et al., 1991). Suckling reflex post-partum and the physiological mechanism during pregnancy prepares udder to produce more milk for does carrying multiple fetuses (Macciotta et al., 2008). Some contrasting theories are also present explaining that there is no effect of litter size on milk composition (Carnicella et al., 2008). Several studies had suggested that seasonal variations such as temperature, relative humidity, rainfall, and solar radiation/photoperiod showed a significant effect on milk physicochemical composition (Clark and García, 2017). Mammary development and subsequent milk production and its composition are influenced by pre-partum photoperiod in dairy cows, ewes, and does.

\section{CONCLUSION}

Lactation length showed a significant effect on lactose, solids nonfat, protein, and freezing point of milk except for fat content in Boer goats within 1 month of parturition. Besides, litter size had a significant influence on the freezing point of milk. Twinning did not significant influence fat, protein, lactose and solids nonfat content of goat milk. All constituents were weakly correlated to litter size however freezing point showed moderately strong correlation. Thus, more focus must be given to the nutritional management of triplets and twins to improve their growth rate compared to a single kid.

\section{DECLARATIONS}

\section{Corresponding Author}

E-mail: saregme@gmail.com; ORCiD: 0000-0003-1856-8780

\section{Competing interest}

We have no conflicts of interest to disclose concerning the research, authorship, and publication of this article.

\section{Acknowledgment}

The authors would like to convey our sincere gratitude to all our mentors in the National Livestock Breeding Office (NLBO) for their continuous guidance and support during our study. We are thankful to the farm management team for providing us with the lab facilities without which our study was impossible.

\section{Authors' contribution}

S.Regmi performed conceptualization, methodology, analysis and writing-original draft; P.Mahato performed conceptualization, methodology, analysis; Kh.R. Sapkota performed writing- review editing.

\section{REFERENCES}

Alkass JE and Merkhan K (2011). Milk production traits of indigenous Black and Meriz goats raised under farm production system. Research Opinions in Animal \& Veterinary Sciences, 1(11):708-713. http://www.roavs.com/pdf-files/Issue_11_2011/708-713.pdf

Amos IBMS (2011). IBM SPSS Statistics 20. helps improve productivity and decision making through analytics.

Banda JW, Steinbach J and Zerfas HP (1992). Milk yield, milk composition and kid growth in Boer and East African goats in Malawi. https://hdl.handle.net/10568/70834

Carnicella D, Dario M, Ayres MCC, Laudadio V, and Dario C (2008). The effect of diet, parity, year and number of kids on milk yield and milk composition in Maltese goat. Small Ruminant Research, 77(1): 71-74. https://doi.org/10.1016/j.smallrumres.2008.02.006

Chilliard Y (1997). Biochemical characteristics of goat milk lipids. A comparison with cow's and human milk. Colloques de I'INRA, France. https://agris.fao.org/agris-search/search.do?recordID=FR1998001566.

Ciappesoni G, Pribyl J, Milerski M, and Mares V (2004). Factors affecting goat milk yield and its composition. Czech Journal of Animal Science, 11:465-473. https://www.agriculturejournals.cz/publicFiles/53274.pdf

Clark S, and García MBM (2017). A 100-year review: Advances in goat milk research. Journal of Dairy Science, 100(12): 10026-10044. https://doi.org/10.3168/jds.2017-13287

Crepaldi P, Corti M, and Cicogna M (1999). Factors affecting milk production and prolificacy of Alpine goats in Lombardy (Italy). Small Ruminant Research, 32(1): 83-88. https://doi.org/10.1016/S0921-4488(98)00156-4

Desbois AP, and SmithnVJ. (2010). Antibacterial free fatty acids: activities, mechanisms of action and biotechnological potential. Applied Microbiology and Biotechnology, 85(6): 1629-1642. https://doi.org/10.1007/s00253-009-2355-3

Greyling JPC, Mmbengwa, VM, Schwalbach LMJ, and Muller T (2004). Comparative milk production potential of Indigenous and Boer goats under two feeding systems in South Africa. Small Ruminant Research, 55(1-3): 97-105. https://doi.org/10.1016/j.smallrumres.2003.11.014

Idamokoro EM, Muchenje V, and Masika PJ (2017). Yield and Milk composition at different stages of lactation from a small herd of nguni, boer, and non-descript goats raised in an extensive production system. Sustainability, 9(6):1000. https://doi.org/10.3390/su9061000

Janštová B, Dračková M, Navrátilová P, Hadra L, and Vorlová L (2019). Freezing point of raw and heat-treated goat milk, Czech Journal of Animal Science, 52: 394-398. https://doi.org/10.17221/2324-CJAS

Kalyankar SD, Khedkar CD, and Patil AM (2016). Goat milk. Encyclopedia of Food and Health (1st ed.). Elsevier Ltd, Amstrdam. https://doi.org/10.1016/B978-0-12-384947-2.00358-5

Knights M, and Garcia GW (1997). The status and characteristics of the goat (Capra hircus) and its potential role as a significant milk producer in the tropics: a review. Small Ruminant Research, 26(3):203-215. https://doi.org/10.1016/S0921-4488(96)00977-7 
Lacasse P, Vinet CM, and Petitclerc D (2014). Effect of prepartum photoperiod and melatonin feeding on milk production and prolactin concentration in dairy heifers and cows. Journal of Dairy Science, 97(6): 3589-3598. https://doi.org/10.3168/jds.2013-7615

Lu, CD (2001). Boer Goat Production : Progress and Perspective. Proceedings of International Conference on Boer Goats. October 20-24, 2001, pp.1-11. https://citeseerx.ist.psu.edu/viewdoc/download?doi=10.1.1.550.3269\&rep=rep1\&type=pdf

Macciotta NPP, Dimauro C, Steri R, and Cappio-Borlino A (2008). Mathematical modelling of goat lactation curves, in: Dairy Goats Feeding and Nutrition, CAB International, UK. pp. 31-46. https://www.cabi.org/cabebooks/ebook/20083075570

Marounek M, Pavlata L, Mišurová L, Volek Z, and Dvořák R (2012). Changes in the composition of goat colostrum and milk fatty acids during the first month of lactation, 2 Czech Journal of Animal Science, 57: 28-33. https://doi.org/10.17221/5481-CJAS

Mestawet TA, Girma A, Ådnøy T, Devold TG, Narvhus JA, and Vegarud GE (2012). Milk production, composition and variation at different lactation stages of four goat breeds in Ethiopia. Small Ruminant Research, 105(1-3): 176-181. https://doi.org/10.1016/j.smallrumres.2011.11.014

Morand-Fehr P, and Sauvant D (1980). Composition and Yield of Goat Milk as Affected by Nutritional Manipulation. Journal of Dairy Science, 63(10): 1671-1680. https://doi.org/10.3168/jds.S0022-0302(80)83129-8

Nepali, JB (2016). Goat Farming Technical Manual. District Livestock Service Office, Gorkha. https://www.jica.go.jp/nepal/english/office/others/c8h0vm0000bjww96-att/tm_7.pdf

Park YW (2009). Impact of goat milk and milk products on human nutrition. CAB Reviews, Cab international, UK. DOI : http://dx.doi.org/10.1079/PAVSNNR20072081

Sauvant D, Hervieu J, Giger S, Ternois F, Mandran N, and Morand-Fehr P (1987). Influence of dietary organic matter digestibility on goat nutrition and production at the onset of lactation. Annales dezootechnie, INRA/EDP Sciences, 36 (3): $335-336$. https://hal.archivesouvertes.fr/hal-00888594/document

Simos EN, Nikolaou EM, and Zoiopoulos PE (1996). Yield, composition and certain physicochemical characteristics of milk of the epirus mountain sheep breed. Small Ruminant Research, 20(1): 67-74. https://doi.org/10.1016/0921-4488(95)00780-6

Simos E, Voutsinas LP, and Pappas CP (1991). Composition of milk of native Greek goats in the region of Metsovo. Small Ruminant Research, 4(1): 47-60. https://doi.org/10.1016/0921-4488(91)90052-R

Singh SN (1990). Studies on the combining ability of desirable characters of important goat breeds, July 1 , 1974 to Dec. 23 , 1985. https://agris.fao.org/agris-search/search.do?recordID=US201300035630

Singh, SN, and Sengar OP S (1979). Studies on the combining ability of desirable characters of important goat breeds for meat and milk separately and in combination; July 1, 1974 to October 31, $1979 . \quad$ https://agris.fao.org/agris search/search.do?recordID=US201300343502

Slaghuis BA (2001). The freezing point of authentic and original farm bulk tank milk in The Netherlands. International Dairy Journal, 11(3):121-126. https://doi.org/10.1016/S0958-6946(01)00043-7

Sung YY, Wu TI, and Wang PH (1999). Evaluation of milk quality of Alpine, Nubian, Saanen and Toggenburg breeds in Taiwan. Small Ruminant Research, 33(1): 17-23. https://doi.org/10.1016/S0921-4488(98)00201-6

Zamuner F, Cameron AWN, and Leury BJ (2020). Effects of month of kidding, parity number , and litter size on milk yield of commercial dairy goats in Australia. Journal of Dairy Science, 103(1): 954-964. https://doi.org/10.3168/jds.2019-17051

Zee B (1982). The freezing point of authentic farm tank milk in the Netherlands. Netherlands Milk and Dairy Journal, 36: 291-303. http://pascal-francis.inist.fr/vibad/index.php?action=getRecordDetail\&idt=PASCAL83X0230078 